\title{
Practice Teachers' Possible Solutions to Students' Problems of Speaking during PPL in Junior High Schools
}

\author{
Chezia Eufresia Isworo \\ Sanata Dharma University
}

\begin{abstract}
Program Pengalaman Lapangan (PPL) or School-based Practicum is one of the compulsory courses that must be taken by all English Language Education Study Program (ELESP) Sanata Dharma University students. PPL requires the students, who are called practice teachers, to do teachers' job at school. As English practice teachers, there is a possibility that they might face a lot of problems related to the condition and situation in the school, either from the students' side, teachers' side, or other factors. This research focuses on junior high school students' problems of speaking and the possible solutions to the problems based on the ELESP students' experiences as English practice teachers. From the findings, it is expected that future practice teachers and English teachers can anticipate similar problems and apply the possible solutions when they work at schools.
\end{abstract}

Keywords: PPL, practice teachers, students' problems of speaking, possible solutions to the problems

\section{Introduction}

In PPL, the ELESP students are expected to be able to understand the concepts and the procedures of a teaching process and to apply them in a real classroom teaching in a high school (junior high school or senior high school). Based on the ELESP Academic Guidelines book (2011, p.43), PPL is designed to train teacher candidates so they can develop integrated and complete teaching skills. Students who take PPL will do teachers' jobs such as planning, developing, and organizing lessons, managing classroom, presenting subject materials, assessing students' learning process and results. Students who are doing PPL are called practice teachers. This research focuses on the practice teachers' possible solutions to students' problems of speaking during PPL in junior high schools.

There are two main reasons why the researcher conducts the research. The first reason is that speaking skill is one of the important language skills. In learning and teaching process, one of the ways practice teachers help students understand English and materials delivered is by speaking English. If practice teachers have difficulties in that area, 
the students' understanding of the materials can be distracted and the goal of the learning English might be hard to reach.

The second reason is the researcher got a story from a teacher of one of the elementary schools, his name is Mr. X (pseudonym). He said that most of his students were good in doing their written tests - they knew how to write down English words, how to spell English words, but when it came to practice speaking, they did not seem to perform well. This case is related to the research topic because in junior high school, the students are still in the transition mode from the elementary school. Their habits of learning English when they were in elementary school might affect the ways they learn and develop their language skills in junior high school. In order to find out the practice teachers' possible solutions to students' problems of speaking in learning process during the teaching practice in junior high schools, two research questions are raised in this research:

1. What were the students' problems of speaking during PPL?

2. What were the possible solutions for the students' problems of speaking during PPL?

\section{Theoretical Ground}

\section{The Nature of Speaking Skill}

Speaking is a basic skill that has a very complicated process. It is because learners need a long time to be competent speakers (Luoma, 2004, p. 1). The students need more experiences and practices to make their speaking ability fluently and naturally. Besides, in speaking learning, the students need to receive and convey the message through oral form and verbal expression (Khadidja, 2010, p. 40). For those students who are studying English as a foreign language, the students can activate their speaking through the dialogues or conversation since the speaking skill requires the practice and experience to be developed.

\section{The Characteristics of} Successful Speaking Activity

Ur (1996, p. 120) emphasizes that "classroom activities that develop learners' ability to express themselves through speech would therefore seem an important component of a language course". He provides some characteristics of successful speaking activity. First, students talk a lot. Second, participation is needed. Teacher as contributor has to distribute the chance fairly. Third, high motivation supports the speaking activity to be successful. Fourth, language is in acceptable level. Students who learn to speak English can express what they want to say related to the material and they can understand what their friends say.

\section{Problems of Learning Speaking \\ Students have their own difficulties in learning language. Munjayanah (2004) states the problems of speaking skill that usually happen in classroom. Some}


of them are inhibition, having no idea about what to say, low or uneven participation, the use of mother tongue. In addition, according to Hetrakul (1995), there are two causes why students have difficulties in speaking English. One of them is that the environment does not support the students to speak English frequently. Others may think that students just want to show off when they speak English for daily conversation. The response that students get makes them loose their self-confidence to improve their speaking. Since students do not want to be rejected by people around them, they use native language in daily conversation.

Davis (2011) states that there are ten common classroom problems that are found while teaching and learning English. The researcher includes some problems that related to learning speaking. They are:

Student is defiant, rowdy, or distracting of others.

In every classroom, the distraction from the students might happen. If the situation in the classroom is not conducive, it may be fault of the teacher, i.e. boring material or poor classroom management. If it is from the students, teachers should take dominant role to adjust the situation.

\section{Personalities between students.}

Davis states that not every student in classroom will become best friend. If there is a drama arises between certain students, the easiest solution is to separate them away from one another. This situation might affect the delivery of material that related to speaking if there are problems between student - students, and also student - teacher.

\section{Methodology}

The researcher used mixed methods in this research. According to Ary, Jacobs, and Razavieh (2002), "Mixed methods research combines quantitative and qualitative research methods in different ways, with each approach adding something to the understanding of the phenomenon." The researcher used questionnaire and interview as the research instrument to obtain the data in this research. The questionnaire was used to frame the answer to the first research question which is about the students' problems of speaking during PPL. The interview was used to clarify the answer to the first research question and to seek the detailed information as the answer to the second research question. The participants of this research were the ELESP students of semester seven batch 2012 who had taken PPL. There were five students as the participants for this research.

\section{Discussion}

1. Problems of Speaking Faced by the Students according to Practice Teachers

Speaking is a basic skill that has a very complicated process. It is because leaners need a long time to be competent speakers (Luoma, 2004 , p. 1). For those students who 
are studying English as a foreign language, students can activate their speaking through the dialogues or conversation since the speaking skill requires the practice and experience to be developed. In fact, based on the participants' experiences as English practice teacher, there are some problems of the students in developing their speaking skill. The researcher divided those problems into four problems. Those problems were:

\section{Students' competence in learning English}

Based on the participants' experiences as English practice teachers, there were some students who did not understand English at all. They had lack of vocabulary and grammar. Some of them also did not know how to pronounce certain words. Their competence in learning English affected their ability in developing their speaking skill. Munjayanah (2004, p.17) states that students might have their own difficulties in learning the language. Particularly improving speaking skill is not easy for the students.

\section{Students' low participation and low motivation in speaking activities}

From the questionnaire results and the interview, the researcher found out that there were some students who had low participation in speaking activities. There were some students who were really active in the class, while the others were not. One of the participants also said that sometimes the students participated actively whenever it was about reward; for example, they got more points if they joined the speaking activity. On the other hand, participant 2 said that their students prefer to write the material rather than to speak in front of the class to present their work. The students only read the material but still did not focus on the speaking skill improvement. Another participant also said that the students had high motivation only when they had group discussion or other learning processes. There was a tendency that the students had low motivation when they learned individually.

The use of mother tongue in speaking activities

Based on the participants' experiences as English practice teacher, most of the students used native language when they were in speaking activities. The researcher asked the participants to percentage the time in speaking English, the one who agreed said that $70 \%$ of time was used for speaking English and $30 \%$ of time was used for bahasa Indonesia. On the other hand, four people who disagreed said the opposite (see Appendix 1 for detail information of questionnaire results). They also said that Javanese was used besides bahasa Indonesia. Hetrakul (1995) states that one of the causes why the students have difficulties in speaking English is that the environment does not support the students to speak in English frequently. It was easier for 
the students to use their mother tongue in their class because they use it every day. This could affect their speaking skill development.

\section{Distractions by the students and their relationship with their classmate(s)}

There were some students who were easily distracted by others when the practice teacher was teaching English in classroom. The distraction was not only from inside the class but from outside class. Participant 1 said that one day when she was teaching speaking, suddenly a student from other class came to borrow a book from her students. The learning activity stopped for a while, and then when she wanted to continue, the students and she forgot the last part of material explained. Sometimes the students were not focusing on the materials because of the distraction happened.

There were some students who were not in a good relationship with their classmate(s) and it influenced their speaking skill development. According to Davis (2010), personalities between students clash and also distraction from the students are the common classroom problems that are found while teaching and learning processes. Another story, there was students who was the captain class and had a crush with his classmate. This class captain was an active student. One day, he looked unmotivated and passive because he was not in a good relationship with his crush. It affected his motivation to learn English because he could not focus on the classroom activity at that time. It did not only influence their speaking skill but also the scores.

\section{The possible solutions to the students' problems of speaking}

There were some possible solutions to the problems in learning speaking based on the participants' teaching experience. The possible solutions were the ways the participants overcome the problems happened when they were teaching English in the class room.

\section{Possible solution to the students' competence in learning English}

Based on the participants' experience, there were some students who wanted to answer the question but they did not understand English at all, so they kept silent because they were confused how to answer the question using English. In this case, the participants usually kept asking questions by using English but then they translated it to bahasa Indonesia in order to make the students know the meaning of the questions. By translating, it helped the students understand the material that is given related to speaking skill and also their vocabularies. Having conversation and giving questions are some ways to develop their speaking skill. Grugeon (2005, p.84) states that when teacher speaks to students about their work, asking questions is the most commonly used strategy to assess their learning and progress. It is also useful to encourage students to think 
independently or individually in an interesting way to question their learning.

Possible solution to students' low participation and low motivation in speaking activities

In this case, the solution is as much as possible, the students has right or chance to speak. According to $\operatorname{Ur}(1996$, p.120), participation is needed. All of the students have to participate in the classroom discussion. They all need to get chance to speak, whether the students are talkative or not, so teacher as the contributor have to distributed the chance fairly. It can also encourage students to be more confident in speaking English. Rivers (1968) also emphasizes that a teacher needs to give many opportunities for students to practice their speaking skill.

Possible Solution to the use of mother tongue by the students in speaking activities

In this case, it depended on the situation and condition of the classroom. If it is not possible for students to understand the material by using English, then do not force them. Participant 1 suggested to use sentence "try to use English" when the students again and again speak bahasa Indonesia or Javanese. The possible solution for this problem is the teacher must create games which can develop their speaking skill, such as, role play, tongue - twister, reading aloud, etc. it depends on each teacher's creativity. Teacher role also affect the students' speaking skill improvement when there is a speaking activity. (Nunan, 2003, p.54)

Possible solution to distraction by the students and their relationship with their classmate(s)

The possible solution to this problem is that when students were busy with their friend during teaching and learning process, just stop and point them out. Asking them about material discussed would make them confused because they did not focus on it. This way could be used in order to make them concentrate on the material. Another possible solution for that problem is making rules before it happened. For example, one of the participants made rules for the student, if they kept busy with their friends; they need to write down ten words in English which had been discussed in the class. If they kept busy with their friends twice, then the "reward" will be multiplied into 20 words and so on. Practice teachers should make sure that the students pay attention to their delivered material and also their comprehension related to speaking skill.

Participant 5 said that she called the troublemaker students to teachers' room and tried to ask them what their concerns were. She also told the students that they could study together with her when there was break time of before English course was started. To increase the students' confidence in speaking English, the teachers can encourage 
the students by telling them that making mistakes were okay. In this case, the teacher also can build a good relationship with the students as a friend.

\section{Conclusion}

The results of the research showed that there were four problems of speaking faced by students, namely students' incompetence in learning English, students' low participation and low motivation in speaking activity, the use of mother tongue, and the distractions from others and their relation with their classmates. The possible solutions to the four problems are written respectively as follows: respecting by translating from English into Indonesian and vice versa, distributing the chance to speak in English fairly to the students, creating games which can develop students' speaking skill and having well-built communication between teacher and students. The results of the research are hopefully useful for future practice teachers and English teachers when they work at schools. Also, it is expected that they can anticipate the similar problems during classroom activity and apply the possible solutions to overcome the problems.

\section{References}

Ary, D., Jacobs, L. C., \& Razavieh., A. (2002). Introduction to research in education $\left(6^{\text {th }} \mathrm{ed}\right)$. Belmont, CA: Wadsworth.

Davis, J. (2011). Teaching ESL: 10 Common Problems in the classroom.

Retreived October 21, 2015, from http:/hubpages.com/hub/Teaching-ESL10Common-Classroom-Problems-and-Solutions.

Grugeon, E., Hubbard, L., \& Smith, C. (2005). Teaching Speaking and Listening in the Primary School. Rouledge: David Fulton Publishers.

Hetrakul, Kavin. (1995). The Second Language. Retrieved October 22 ${ }^{\mathrm{n}}$ 2015, from http://eserver.org/courses/spring95/76-100g/KavinHetrakul.html

Khadidja. (2010). The Effect of classroom interaction on developing the learner's speaking skill. Retrieved October 21 ${ }^{\text {st }}$, 2015, from http://www.umc.edu.dz/thesis/anglais/KOU1159.pdf

Luoma, S. (2004). Assessing speaking. Cambridge: Cambridge University Press.

Munjayanah, A. (2004). The Implementation of communicative language teaching speaking at LIA. Retrieved October $21^{\text {st }}, 2015$, from

http://eprints.ums.ac.id/27781/1.pdf

Rivers, W. M. (1968). Teaching foreign language skills. Chicago, FL: The University of Chicago Press.

Tutyandari, C., Prasetyo, H., Kristiani, C., \& Bram, B. (Eds.). (2011). Panduan Akademik Program Studi Pendidikan Bahasa Inggris. Yogyakarta: Program Studi Pendidikan Bahasa Inggris Universitas Sanata Dharma.

Ur, P. (1996). A Course in language: teaching practice and theory. Cambridge: Cambridge University Press. 